\title{
Anti-Proliferative Effects of Selenium in HT-29 Colon Cancer Cells via Inhibition of Akt
}

\author{
Song Yi Park', In-Seop Kim', Se Hee Lee', Sol Hwa Lee', Da Woon Jung', Ock Jin Park ${ }^{2}$ and Young \\ Min $\mathrm{Kim}^{1} *$
}

\author{
${ }^{1}$ Department of Biological Sciences, College of Life Science and Nano Technology, Hannam University, Daejeon 305-811, Korea \\ ${ }^{2}$ Department of Food and Nutrition, College of Life Science and Nano Technology, Hannam University, Daejeon 305-811, Korea
}

Received October 18, 2011 /Revised December 26, 2011 /Accepted December 29, 2011

\begin{abstract}
Akt is known to play an important role in cell proliferation and differentiation, and is also over-expressed in several types of cancer cells. In this study, we explored the anti-proliferative effects of selenium in HT-29 colon cancer cells, mediated through effects on Akt and COX-2. Selenium treatments at different concentrations and for different durations inhibited proliferation of HT-29 colon cancer cells and increased apoptotic cell death. Selenium treatment decreased Akt phosphorylation and COX-2 expression. Treatment with LY294002 (an Akt inhibitor) decreased proliferation of HT-29 cells, while a combined treatment with LY294002 and selenium resulted in even further decreases in cell proliferation. Inactivation of Akt by Akt siRNA treatment abolished these inhibitory effects on cell growth. COX-2 expression decreased in Akt transfected cells compared to non-transfected cells. These results suggest that selenium induced both anti-proliferative and apoptotic effects by inhibiting Akt phosphorylation and COX-2 expression. Selenium treatment also appeared to induce synergistic anti-proliferative effects by inhibition of Akt in HT-29 colon cancer cells.
\end{abstract}

Key words : Selenium, anti-proliferatory effect, HT-29 colon cancer cells, Akt siRNA, COX-2

\section{서 론}

대장암은 전 세계적으로 발병률이 높은 5 대 암중의 하나이 며, 국내에서도 서구화된 식습관에 의하여 매년 증가하는 추 세에 있다. 대장암을 치료하기 위한 대체의학에 대한 관심이 높아짐에 따라 여러 가지 식품 추출물들을 통한 암예방 효과 에 대한 연구가 많이 진행되고 있다. 그 중에서도 대장암을 비롯한 여러 암종에서 암예방효과를 나타내는 것으로 보고된 대표적인 것으로 셀레늄(selenium)이 있다. 셀레늄은 우리 몸 에 필수적인 미량원소로 항산화 효과 및 항암효과를 나타내는 것이 보고된 바 있으며, NF- $\mathrm{kB}$ 와 같은 전사인자들의 활성을 제어함으로써 대장암을 비롯한 여러 암종에서 암세포의 성장 을 억제하고 DNA, RNA 및 단백질의 합성을 억제하는 것으로 알려져 있다[5,7,21]. Clark [4] 등은 1996년에 임상실험을 통하 여 매일 $200 \mu \mathrm{g}$ 의 셀레늄을 4년 6개월 동안 섭취한 결과 셀레 늄을 섭취한 그룹의 사람들의 전체 암 발생률이 $37 \%$, 특히 전립선암의 발생률은 $63 \%$, 대장암의 발생률은 $58 \%$, 폐암의 발생률은 $46 \%$ 가 낮게 나타난다고 보고하였다. 최근 연구에서 HT-29 대장암세포에 셀레늄을 처리하였을 때 in vitro 실험에 서 암세포의 증식을 억제하고 apoptosis를 유도하였으며 HT-29 세포 mouse xenograft model에서 셀레늄 처리에 의하

*Corresponding author

Tel : +82-42-629-8753, Fax : +82-42-629-8751

E-mail : kym@hnu.kr
여 종양의 성장이 억제되는 것으로 보고되었다[14].

Protein kinase B라 불리는 Akt는 serine/threonin kinase로 upstream kinase인 PI3K 경로를 통해 활성화 되는 것으로 알 려져 있으며, 세포의 증식과 분화, 혈관신생 등 여러 생리활성 을 조절하는 매우 중요한 조절자로서 작용한다. PI3K/ Akt 신호경로는 여러 암종에서 과활성화 되어 있다고 보고된 바 있으며 인슐린과 같은 자극 인자들에 의해 PI3K로 신호가 전 달되면 Akt가 세포질에서 세포막으로 이동하면서 serine 473 잔기가 인산화되어 활성화 형태가 된다[1]. 이러한 활성을 통 하여 $\mathrm{Akt}$ 는 하위분자인 GSK3 $\beta, \mathrm{FOXOs}$ 그리고 mTOR 등을 활성화시켜 세포의 증식과 분화를 촉진시키고, proapoptotic 인자인 BAD, procaspase-9, forkhead (FKHR) 전사인자 등을 비활성화 시킴으로써 세포의 자연사멸을 억제하는 것으로 알 려져 있다[2,17].

Cyclooxygenase (COX)는 세포 내에서 COX-1및 COX-2의 두 가지 isoform으로 존재하며 COX-1은 위, 대장, 혈소판을 비롯한 대부분의 조직에서 발현되며 세포를 보호하는 역할을 한다. COX-2는 cytokines, 성장인자, 발암유전자 등에 의해 활 성화 되는 것으로 알려져 있으며 많은 암종에서 COX-2가 과 발현되어 있다고 보고된 바 있다[23]. 특히 대장암에서 COX-2 가 과발현되어 있다고 보고되었으며 COX-2의 저해제를 처리 하였을 때 대장암 세포의 증식을 억제하고 대장암 예방효과를 나타내는 것으로 보고 되었다[8]. 따라서 본 연구에서는 HT-29 세포에 셀레늄을 처리하였을 때 암세포의 증식이 억제되는지 
알아보았고, 암세포의 증식억제효과에 있어서 암세포의 증식 과 분화, 전이에 관여하는 Akt의 활성을 억제하였을 때 일어나 는 세포증식억제의 시너지 효과를 알아보고자 하였다.

\section{재료 및 방법}

\section{재료}

본 실험에서 사용된 셀레늄은 Sigma (Sigma Aldrich, St. Louis, $\mathrm{MO}$ )에서 구입하여 증류수에 녹인 뒤 $10 \mathrm{mM}$ stock으로 만들어 $-20^{\circ} \mathrm{C}$ 에 보관하여 사용하였다. 3-(4,5-dime thylthiazol-2-yl)-2.5-diphenyltetrzolium bromide (MTT)는 Sigma (Sigma Aldrich, St. Louis, MO)에서 구입하여 $5 \mathrm{mg} / \mathrm{ml}$ stock 으로 만들어서 사용하였다. 또한, celecoxib와 LY294002는 Calbiochem (San Diego, CA)에서 구입하여 DMSO에 녹인 뒤 각각 $25 \mathrm{mM}$ 과 $10 \mathrm{mM}$ stock으로 만들어 사용하였다.

\section{세포 배양}

HT-29 세포는 American Type Culture Collection (ATCC, Rockville, $\mathrm{MD}, \mathrm{USA}$ )에서 분양 받았으며, $10 \%$ 우태아혈청 (fetal bovine serum, FBS, Gibco BRL, Grand Island, NY, USA)과 $1 \%$ antibiotics $(100 \mathrm{mg} / 1$ streptomycin, $100 \mathrm{U} / \mathrm{ml}$ penicillin)가 포함된 RPMI 1640 배지(WelGENE Inc., Seoul, Korea)를 사용하여 $5 \% \mathrm{CO}_{2}, 37^{\circ} \mathrm{C}$ 조건 하에서 배양하였다. 매 48시간마다 Trypsin-EDTA (WelGENE Inc., Seoul, Korea) 를 이용하여 세포를 부유상태로 만든 다음 세포를 $1 \times 10^{6}$ 개 $/ \mathrm{ml}$ 로 분주하고 계대하여 실험에 사용하였다.

\section{MTT assay에 의한 암세포의 생존율 측정}

세포배양용 12 well plate에 HT-29 세포를 $1 \times 10^{4}$ 개/ml로 분주하고 24시간 동안 배양시킨 후 셀레늄을 처리하였다. Celecoxib와 LY294002를 처리시에는 celecoxib와 LY294002 를 30분 먼저 처리한 후 셀레늄을 처리하였으며 MTT 용액(5 $\mathrm{mg} / \mathrm{ml}$ )을 $30 \mu \mathrm{l}$ 씩 첨가하여 1시간 동안 $\mathrm{CO}_{2}$ incubator에서 배양하였다. MTT시약이 들어있는 배지를 제거한 후에 $\mathrm{DMSO}$ 를 $150 \mu \mathrm{l}$ 넣어 well에 생성된 formazan을 모두 녹인 후, 96 well plate에 100 lㅣ씩 옮겨서 Microplate Reader (BIO-RAD Laboratories, Inc. USA)로 $595 \mathrm{~nm}$ 에서 흡광도를 측정하였다. 측정은 모두 세 번 하였으며, 그에 따르는 평균 값과 표준오차는 Microsoft Excel program을 이용하여 분석 하였다.

\footnotetext{
Fluorescence-Activated Cell Sorting (FACS)에 의 한 apoptosis 관찰

Apoptosis는 FITC-Annexin V apoptosis detection kit (BD Pharmingen ${ }^{\mathrm{TM}}$, San Diego, CA, USA)를 사용하여 측정하였 다. AnnexinV-PI staining을 하기 위해, HT-29 세포에 celecox-
}

ib $25 \mu \mathrm{M}, \mathrm{LY} 29400220 \mu \mathrm{M}$ 을 30분 먼저 처리한 후 셀레늄 $0.25 \mathrm{mM}$ 을 처리하여 24시간 배양하였다. 처리된 세포는 차가 운 PBS로 세척하고 나서 trypsin-EDTA로 모은 다음, $1 \times 10^{6}$ 개 $/ \mathrm{ml}$ 의 농도에서 binding buffer로 suspension하였다. 그 다음 에 $1 \times 10^{5}$ 개의 HT-29 세포를 Annexin V-FITC와 prodipium iodide (PI)로 15분간 염색한 후, 1 시간 정도 flow cytometry (Becton-Dickinson Biosciences, Drive Frankline Lages, NJ, $\mathrm{USA})$ 로 분석하였다.

\section{Western blotting}

셀레늄을 농도 별로 처리한 후 6시간 동안 $\mathrm{CO}_{2}$ incubator에 서 배양한 후, 단백질을 추출하기 위하여 RIPA lysis buffer [50 mM Tris- $\mathrm{HCl}$ (pH 8.0), $150 \mathrm{mM} \mathrm{NaCl}, 1 \% \mathrm{NP}$ 40, 0.5\% sodium deoxycholate, $1 \mathrm{mM}$ phenylmethysulfonyl]를 각 well에 $150 \mu$ 씩 첨가하여 반응시킨 후, $14,000 \mathrm{rpm}, 4^{\circ} \mathrm{C}$ 에서 20 분 동안 원심분리 하여 상등액을 취하였다. 그런 다음, ELISA-reader $595 \mathrm{~nm}$ 에서 흡광도를 측정하여 각 표본의 단백 질 농도를 결정하였다. $5 \times$ Laemmi sample buffer (loading dye; $250 \mathrm{mM}$ Tris-Cl (pH 6.8), 40\% glycerol, $4 \% \quad \beta$ -mercaptoethanol, $0.08 \%$ bromophenol blue, $8 \%$ SDS)와 HT-29 세포에서 추출한 단백질을 혼합하여 표본을 제작한 후, $\mathrm{p}$-Akt, COX-2, $\beta$-actin의 1차 항체를 Cell Signaling Technology (Beverly, MA, USA)로 부터 구입하여 각각 희석 한 후, 반응시켰다. 2차 항체는 GenDEPOT (Barker, TX)에서 구입하여 각각 희석하여 1시간 반응시킨 다음, LAS-4000 (Fuji Film, Japan)을 이용하여 감광하였다.

\section{Immuofluorescence}

셀레늄 $0.5 \mathrm{mM}$ 을 처리한 후 6시간 동안 $\mathrm{CO}_{2}$ incubator에서 배양한 뒤 배지를 제거하고 $3.5 \%$ formaldehyde에 20 분간 고 정 한 뒤 $0.1 \%$ triton X-100 용액에 permiabilization 하였다. 그런 다음 $1 \% \mathrm{BSA}$ 용액에 넣고 1시간 blocking한 후, p-Akt, COX-2의 1차 항체를 Cell Signaling Technology (Beverly, $\mathrm{MA}, \mathrm{USA}$ )로 부터 구입하여 각각 희석하여 반응시켰다. 2차 항체는 Invitrogen (Carlsbad, CA)에서 Alexa488 (green)과 Alexa546 (red)을 구입하여 각각 희석하여 1시간 반응시킨 다 음, confocal microscope (Carl Zeiss, USA)를 이용하여 감광하 였다.

\section{Small interfering RNA (siRNA) transfection}

siRNA transfection에 필요한 Akt1 siRNA와 Dharmafect는 Dharmacon (Lafayette, $\mathrm{CO}$ )에서 구입하여 transfection을 실 시하였다. 세포를 plate에 $1 \times 10^{4}$ 개 $/ \mathrm{ml}$ 로 분주한 뒤 24 시간 동 안 $\mathrm{CO}_{2}$ incubator에서 배양한 후 $5 \mathrm{nmol}$ 의 Akt1 siRNA와 Dharmafect, 그리고 media를 반응시킨 다음 각 well당 $1 \mathrm{ml}$ 씩 분주한 뒤 48 시간 동안 $\mathrm{CO}_{2}$ incubator에서 배양하였다. 48 시 
간 후 새로운 media로 바꿔 준 뒤에 72 시간 후 셀레늄 0.25 $\mathrm{mM}, 0.5 \mathrm{mM}$ 을 처리한 다음 24시간 동안 $\mathrm{CO}_{2}$ incubator에서 배양한 후 MTT assay를 실시하였다. Western blotting의 경우 6 well plate에 각 well당 $2 \mathrm{ml}$ 씩 분주한 뒤 72 시간 후 셀레늄 $0.5 \mathrm{mM}$ 을 처리한 다음 6시간 후에 RIPA lysis buffer를 이용하 여 수행하였다.

\section{통계처리}

통계 프로그램인 SPSS 17.0 을 사용하여 실험설계에 대한 분산분석은 ANOVA로, 각 처리군들 과의 비교는 일원배치 분산분석을 실시하여 검정하였다. 각 자료는 3 번 이상의 반복 된 실험을 통하여 얻어진 결과로 검정하였고 $p<0.05$ 인 경우 통계적으로 유의하다고 판정하였다.

\section{결 과}

셀레늄이 HT-29 대장암 세포의 증식과 사멸에 미치는 영향 본 연구에서는 셀레늄이 HT-29 세포의 증식에 미치는 영향 을 알아보기 위하여 셀레늄을 농도별 $(0.125 \mathrm{mM}, 0.25 \mathrm{mM}, 0.5$ $\mathrm{mM}, 1 \mathrm{mM})$ 과 시간별 $(0,3,6,12,24 \mathrm{hr})$ 로 처리한 후 세포 생존율을 측정하였다. 그 결과 Fig. $1 \mathrm{~A}$ 와 같이 셀레늄을 농도 별로 24시간 처리하였을 때 $0.125 \mathrm{mM}$ 에서는 약 $78 \%, 0.25 \mathrm{mM}$ 에서는 약 $61 \%, 0.5 \mathrm{mM}$ 에서는 약 $34 \%$ 그리고 $1 \mathrm{mM}$ 에서는 약 $12 \%$ 로 농도 의존적으로 세포의 증식이 억제됨을 확인하였 다. 또한 Fig. $1 \mathrm{~B}$ 에서와 같이 셀레늄 $0.25 \mathrm{mM}$ 을 시간별로 처리 하였을 때 1 시간 후에는 $98 \%$ 로 크게 차이가 없었으나 3 시간 후부터 통계적으로 유의하게 세포의 증식이 억제됨을 확인하 였다.

셀레늄에 의한 HT-29 세포의 apoptosis 유도 효과 셀레늄이 HT-29 세포의 apoptosis에 미치는 영향을 관찰하
기 위하여 셀레늄 $0.5 \mathrm{mM}$ 을 처리하여 Annexin V-PI 염색을 통해 apoptosis시 나타나는 phosphatidyl serine의 발현을 측 정해 보았다. 그 결과 셀레늄을 처리하였을 때 phosphatidyl serine을 측정하는 Annexin V 염색시약에 positive한 세포의 수가 증가하는 것을 확인하였다(Fig. 2). 따라서 HT-29 세포의 증식억제에 있어서 셀레늄이 효과적으로 작용하며, 세포의 apoptosis를 유도함을 확인하였다.

셀레늄에 의한 p-Akt, COX-2 신호단백질의 발현 조절

HT-29 세포에 셀레늄을 농도별로 6시간 처리하여 p-Akt와 $\mathrm{COX}-2$ 의 신호단백질의 조절 양상을 알아보기 위하여
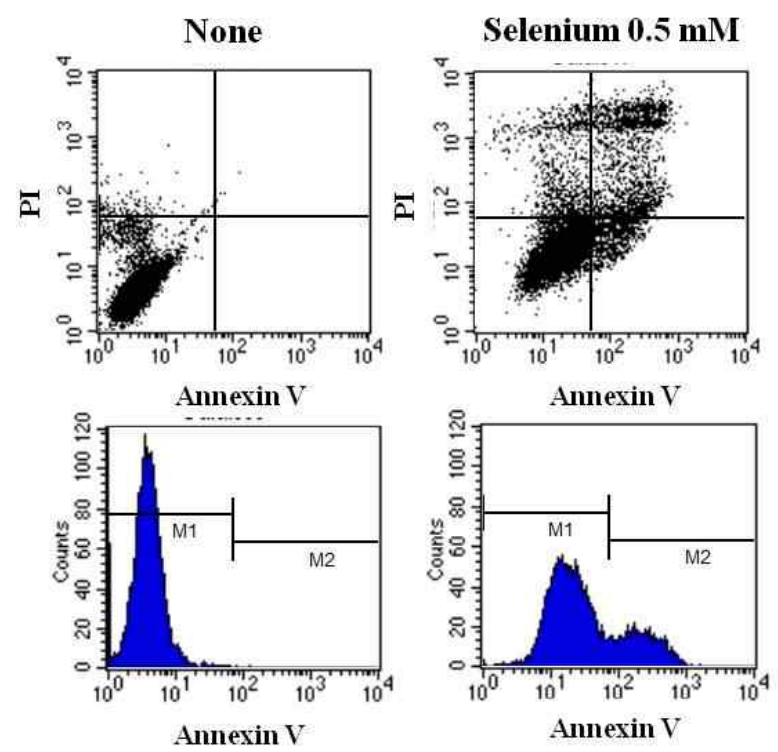

Fig. 2. Treatment of selenium induces apoptosis in HT-29 colon cancer cells. Cells were treated with selenium $0.5 \mathrm{mM}$. Apoptosis was measured by Annexin V-fluorescein isothiocyanate and popidium iodide.
(A)

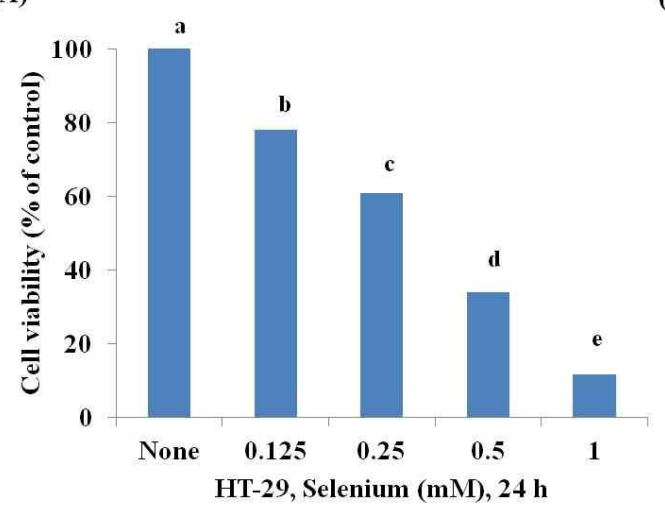

(B)

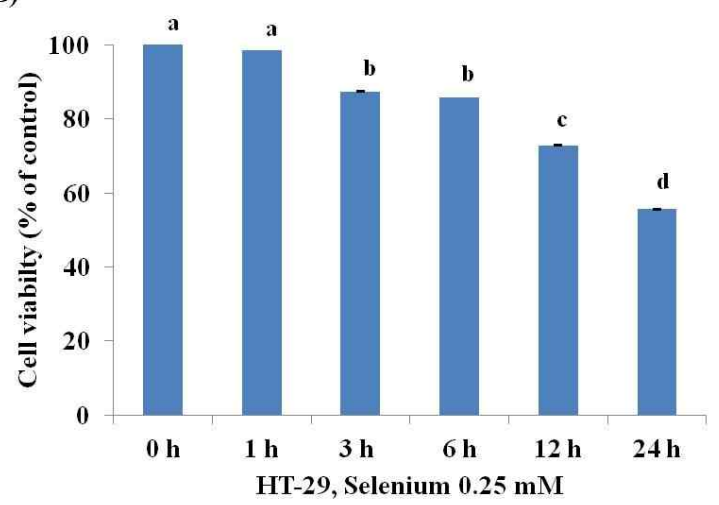

Fig. 1. Selenium inhibits cell proliferation in HT-29 colon cancer cells. Cell viability was measured by MTT assay. Treatment of selenium inhibits cell proliferation. Cells were treated with $0.125-1 \mathrm{mM}$ of selenium (A). Cells were treated with selenium $0.25 \mathrm{mM}$ in 1-24 hr (B). a,b,c,d,e; $p<0.05$ (each experiment's $\mathrm{n}=3$ ) 


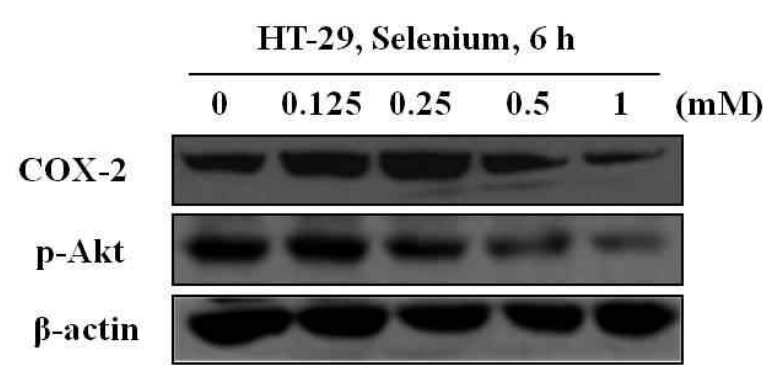

Fig. 3. Selenium effects on p-Akt and COX-2 in HT-29 colon cancer cells. Cells were treated with $0.125-1 \mathrm{mM}$ of selenium. Protein levels of them were determined by Western blotting.

Western blotting을 실시하였다. Fig. 2에 나타난 바와 같이 셀레늄을 $0.125 \mathrm{mM}, 0.25 \mathrm{mM}, 0.5 \mathrm{mM}, 1 \mathrm{mM}$ 로 처리했을 때, 농도에 의존적으로 p-Akt와 COX-2의 발현이 감소하는 것 을 확인하였다. 또한 셀레늄 $0.5 \mathrm{mM}$ 을 6시간 처리하여 immunofluorescence를 실시한 결과, 셀레늄을 처리하였을 때 세 포질 내부에 활성화 되어 있는 p-Akt (red)의 발현이 저해되었 으며, 세포질 및 핵내 발현이 증가되어 있던 COX-2 (green)가 감소하였다(Fig. 4).

Akt, COX-2 저해제 처리 및 Akt siRNA가 HT-29 세포 의 증식에 미치는 효과

Akt의 저해제인 LY294002와 COX-2의 저해제인 celecoxib 를 셀레늄과 병행처리하였을 때 HT-29 세포의 증식에 미치는 영향을 알아보기 위하여 MTT assay를 실시하였다. Fig. 5에서 와 같이 LY294002 $20 \mu \mathrm{M}$, celecoxib $25 \mu \mathrm{M}$, 셀레늄 $0.25 \mathrm{mM}$ 을 24 시간 동안 각각 그리고 병행처리하였을 때의 암세포의 증식 을 확인한 결과, LY294002를 단독으로 처리하였을 때에는 약

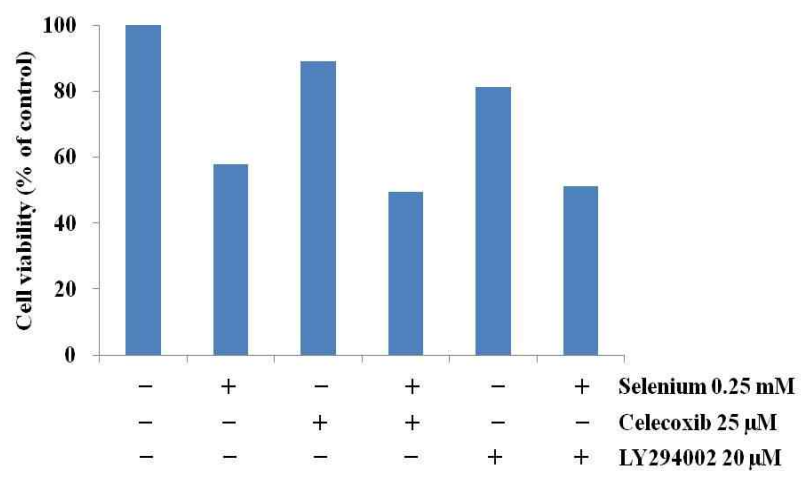

Fig. 5. Selenium inhibited cell growth through p-Akt and COX-2 inhibition in HT-29 colon cancer cells. $0.25 \mathrm{mM}$ selenium was treated with $25 \mu \mathrm{M}$ of Celecoxib or $20 \mu \mathrm{M}$ of LY294002. HT-29 cells were pre-treated with $25 \mu \mathrm{M}$ of Celecoxib or $20 \mu \mathrm{M}$ of LY294002. Cell viability was measured by MTT assay.

$81 \%$ 의 생존율을 보였고, 셀레늄과 LY294002를 병행처리하였 을 때에는 약 $51 \%$ 의 생존율을 보였다. 또한 celecoxib를 단독 으로 처리하였을 때에는 약 $89 \%$ 의 생존을 보였으나 셀레늄과 celecoxib를 병행처리하였을 때에는 약 $49 \%$ 의 생존율을 나타 내었다. 이와 같이 셀레늄과 Akt, COX-2의 저해제를 병행처리 한 결과가 셀레늄을 단독으로 처리하였을 때 보다 세포증식억 제 효과가 더 강하게 나타나는 것을 확인하였다.

HT-29 세포에 Akt siRNA를 이용하여 gene knockdown을 시킨 뒤 세포증식억제 효과를 알아보기 위하여 MTT assay를 실시하였다. 그 결과 Fig. 6에서와 같이 control군에서는 셀레 늄을 $0.25 \mathrm{mM}$ 처리하였을 때 약 $57 \%$ 의 생존률을 보였으나 동일한 조건에서 Akt siRNA transfection 군에서는 약 $43 \%$ 의 생존율을 보였다. 셀레늄을 $0.5 \mathrm{mM}$ 처리하였을 때에도 con-
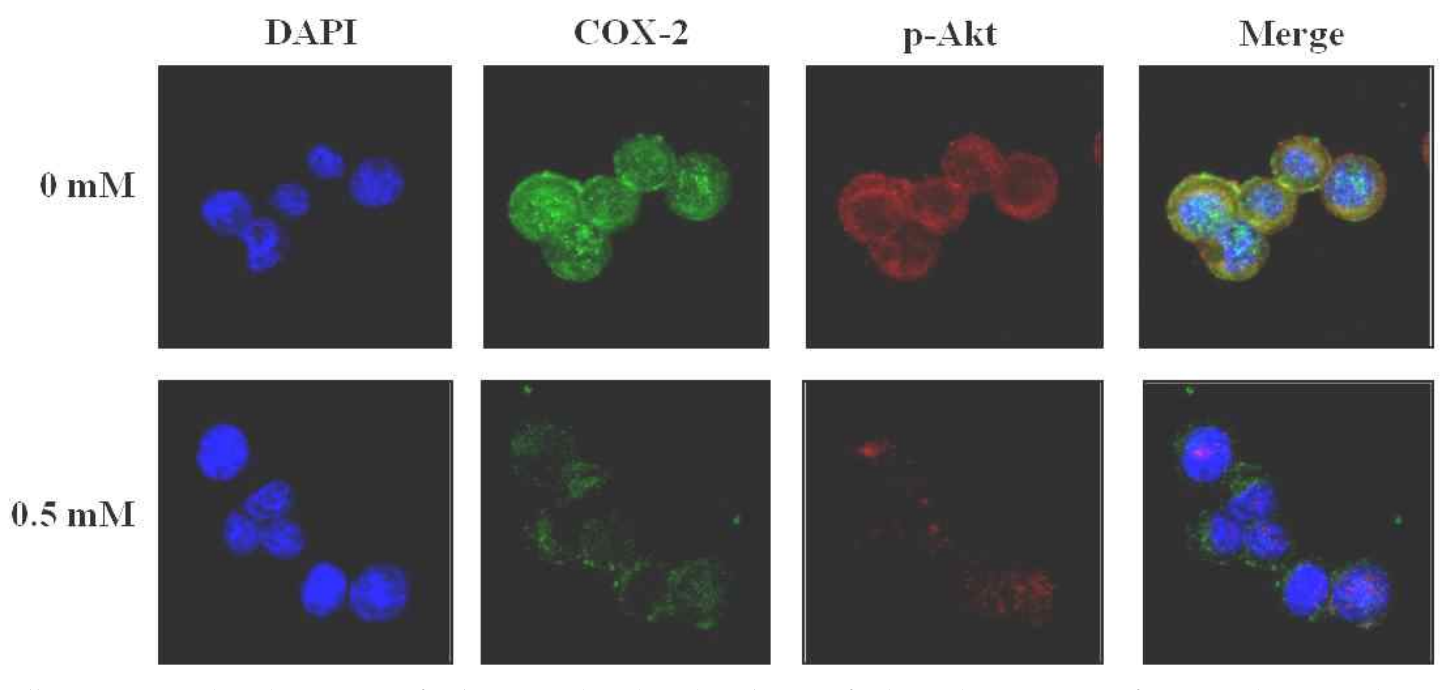

Fig. 4. Cells were treated with $0.5 \mathrm{mM}$ of selenium. The phosphorylation of Akt and expression of COX-2 shown with immune-fluorescence staining using Alexa 488 (green), Alexa 546 (red) and nuclei shown with Hoechst 33342 dye (blue) (B). 


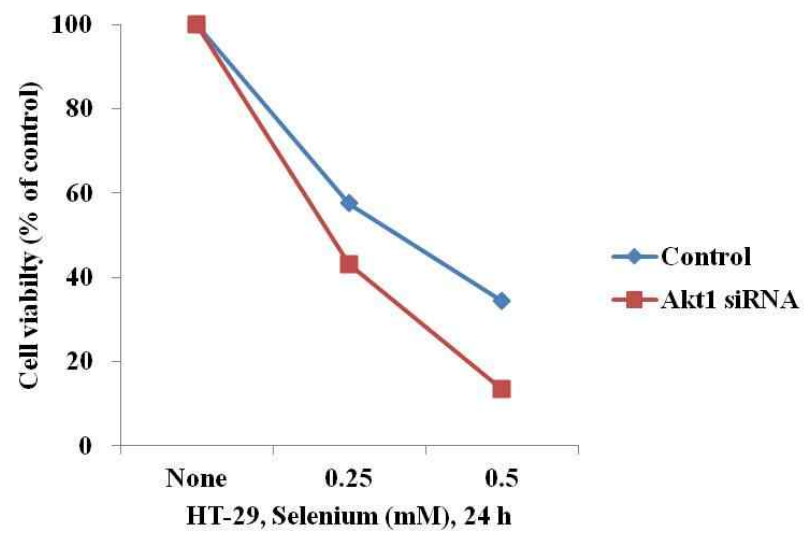

Fig. 6. Inhibition of cell growth through Akt deficiency in selenium treated HT-29 cells. Cells were transiently transfected with p-Akt1 siRNA or a nonspecifiec siRNA (control) for $72 \mathrm{hr}$ and treated with selenium (0.25-0.5 $\mathrm{mM}$ ). Cell viability was measured by MTT assay (A).

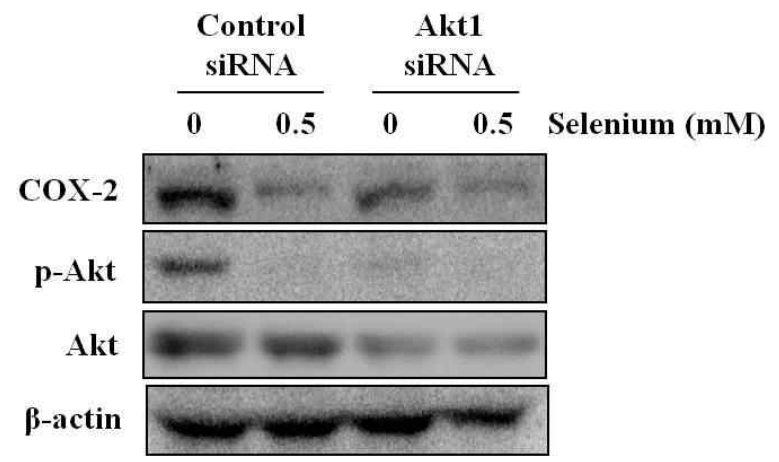

Fig. 7. Regulation of COX-2 by Akt dependency in selenium treated HT-29 cells. Cells were transiently transfected with p-Akt1 siRNA or a nonspecifiec siRNA (control) for $72 \mathrm{hr}$ and treated with $0.5 \mathrm{mM}$ of selenium for 6 hr. Protein levels of p-Akt and COX-2 were detected by Western blotting.

trol군에서는 약 $34 \%$ 의 생존률을 보였으나 Akt siRNA transfection 군에서는 약 $13 \%$ 생존율을 나타내었다.

\section{Akt SiRNA에 의한 셀레늄의 COX-2 신호분자의 조절}

$\mathrm{Akt}$ 가 COX-2를 조절하는 조절자로서 작용할 수 있는지 알 아보기 위하여 Akt siRNA를 이용하여 gene을 knockdown 시킨 뒤 셀레늄을 $0.5 \mathrm{mM}$ 처리하여 COX-2의 발현을 확인하 였다. 그 결과 Fig. 7에서와 같이 control군에 비하여 Akt siRNA transfection 군에서의 COX-2 발현은 약하게 나타났으 나 COX-2의 발현이 완전히 저해되지는 않았으며 셀레늄을 처리하였을 때 아무것도 처리하지 않은 none에 비하여 COX-2 의 발현이 저해된 것을 확인하였다. 이러한 결과는 셀레늄이 Akt 경로를 거치지 않고도 COX-2의 발현을 저해하는 것으로 보인다.

\section{고 찰}

셀레늄은 우리 몸에 필수적인 미량원소로, 단백질을 구성하 고 여러 생화학적 기능을 하며, 생체내에서 주로 유기 형태인 셀레노메티오닌(selenomethionin, Sem) 및 셀레노시스테인 (selenocysteine, Sec), 항산화효소와 셀레노시스테인을 포함 하는 셀레노 단백질로 존재한다[19]. 셀레늄은 항산화 작용 및 면역기능 강화, 항암효과를 가지고 있다는 연구가 보고되었 다. 셀레늄은 산화적 스트레스를 받았을 때 glutathione peroxidase와 같은 항산화효소를 생성해 내어 항산화 작용을 하는 것으로 알려져 있다[18]. 또한 여러 암세포종에서 세포성장을 억제하며, 전사인자의 활성을 조절하여 암세포의 세포사멸을 유도하는 것으로 알려져 있다[5,7,21].

$\mathrm{Akt}$ 는 대장암을 비롯한 여러 암종에서 과발현되어 있다고 보고되었으며 물질대사, 세포 성장, 생합성, 분화 그리고 apoptosis의 억제와 같은 세포내 활동에 다양한 영향을 미치 는 것으로 알려져 있다[9]. Akt는 anti-apoptotic protein인 cyclic- AMP response element-binding protein (CREB) 등을 활 성화 시키며 $\mathrm{I} \kappa \mathrm{B}$ 를 인산화 시키는 I $\mathrm{KB}$ kinase (IKK)를 활성화 하여 $\mathrm{I} \kappa \mathrm{B}$ 를 분해하고, NF- $\mathrm{kB}$ 가 핵 내로 이동시킴으로써 여러 발암유전자들의 발현을 촉진시키는 것으로 보고되었다[3, 15]. 뿐만 아니라 Wnt 신호경로의 주요 조절자인 GSK3 3 의 인산화 를 촉진시킴으로써 Wnt 신호경로의 전사인자인 $\beta$-catenin의 핵 내 이동을 촉진하는 것으로 보고되었다[10]. Akt가 암세포 의 증식과 성장에 관여하는 신호경로들에서 중요분자로서 작 용하고 있다는 보고에 따라, 본 연구에서는 HT-29 세포에 셀 레늄을 처리하였을 때 세포증식억제 효과를 알아보았고, Akt 의 활성억제에 따른 세포증식억제의 시너지 효과를 알아보고 자 하였다. 이를 위하여 먼저 셀레늄을 농도별과 시간별로 처 리하여 HT-29 세포의 생존율을 측정하였다. Fig. 1A, B에서 보이는 바와 같이 아무것도 처리하지 않은 대조군에 비하여 셀레늄을 농도별로 처리하였을 때, 셀레늄의 농도가 높아짐에 따라 HT-29 세포의 생존율이 감소하였고, Fig. 2에서와 같이 이러한 암세포의 생존율 감소가 apoptosis에 의한 것임을 확 인하였다. 선행연구들에서 HT-29 세포 및 Hep3B 간암세포에 셀레늄을 처리하였을 때 세포의 증식이 억제되고 apoptosis가 일어난다고 보고되었으며, 선행연구 및 본 실험에서 수행한 연구결과를 통하여 셀레늄이 암세포의 증식을 억제하고 apoptosis 유도효과가 있음을 확인 할 수 있었다[12,20].

셀레늄의 세포증식억제 효과에 있어서 세포증식에 관여하 는 Akt 및 COX-2 신호분자의 활성을 Western blotting을 통해 관찰한 결과, Fig. 3에서와 같이 셀레늄을 농도별로 처리하였 을 때 Akt의 활성형인 $\mathrm{p}-\mathrm{Akt}$ 의 발현은 감소하였고, COX-2의 발현 역시 감소하였다. 최근 연구에서 ER-negative, HER2positive한 유방암에서 COX-2의 과 발현은 Akt 신호경로의 활성을 통하여 일어난다고 보고되었다[6]. 따라서 Akt가 세포 
내에서 COX-2와 결합하여 신호전달을 촉진하는지 알아보기 위하여 immunofluorescence를 실시한 결과, Fig. 4에서 나타 난 바와 같이 셀레늄에 의하여 p-Akt와 COX-2의 발현은 감소 되지만 p-Akt는 세포질에서 발현이 조절되며, COX-2는 핵내 에서 발현이 조절되어 둘이 결합하여 작용하는 것은 아님을 확인할 수 있었다. Akt와 COX-2가 HT-29 대장암세포의 증식 에 미치는 영향을 알아보기 위하여 Akt의 저해제인 LY294002 와 COX-2의 저해제인 celecoxib를 처리하여 세포 생존률을 측정한 결과, Fig. 5 에 나타난 바와 같이 LY294002와 celecoxib 를 처리하였을 때 세포의 증식이 억제됨을 확인하였고, 이들 저해제를 셀레늄과 병행처리하였을 때 셀레늄의 세포증식억 제효과가 더 높게 나타남을 확인하였다. 최근 연구들에서 셀 레늄이 PI3K/Akt 신호경로를 저해한다고 보고되었으며, 혈관 내피세포에서 셀레늄을 처리하였을 때 COX-2의 발현이 저해 된다고 보고되었다[16]. 또한 간세포의 간암형성에 있어서 $\mathrm{Akt}$ 와 COX-2 신호경로의 활성이 매우 중요한 역할을 하고 있다고 보고되었고, COX-2의 upstream으로 Akt와 ERK가 작 용할 수 있다고 보고되었다[11,22]. 이러한 선행연구 및 본 실 험에서 수행한 연구결과를 비교해 보았을 때, 셀레늄을 처리 하였을 때 일어나는 HT-29 세포의 증식억제에 p-Akt 및 $\mathrm{COX}$-2의 발현저해가 중요한 역할을 하는 것으로 보여진다.

Akt siRNA를 이용하여 gene knockdown을 시켰을 때 HT-29 세포의 증식 및 COX-2 신호분자의 발현 조절을 알아보 기 위하여 MTT assay 및 Western blotting을 실시하였다. 그 결과 Fig. 6에 나타난 바와 같이 셀레늄을 처리하였을 때 control군에 비하여 Akt siRNA transfection군에서 더 강하게 세 포의 증식이 억제되는 것을 확인하였다. 선행연구들을 통해 Akt가 COX-2의 upstream으로 작용할 수 있다는 보고에 따라 본 연구에서 Akt siRNA transfection을 통하여 COX-2의 조절 양상을 확인한 결과, Fig. 7에 나타난 바와 같이 Akt siRNA transfection군에서 non-transfection군에 비하여 아무것도 처 리하지 않은 none의 COX-2 발현이 더 감소되었을 확인하였으 며 Akt siRNA transfection군에 셀레늄 $0.5 \mathrm{mM}$ 을 처리하였을 때 COX-2의 발현이 저해되는 것을 확인하였다. 따라서 앞선 선행연구 및 본 연구결과를 통하여 HT-29 대장암세포의 증식 억제효과는 Akt와 COX-2신호분자의 조절을 통해 일어나며, $\mathrm{Akt}$ 의 활성억제가 COX-2의 발현 조절에도 영향을 미칠 수 있음을 확인할 수 있었다. 최근 연구들에서 HT-29 대장암세포 주에 커큐민을 처리하였을 때 AMP-activated protein kinase (AMPK)가 COX-2를 저해한다는 것이 보고되었으며, 셀레늄 을 처리하였을 때 $\mathrm{Akt}$ 의 저해는 $\mathrm{AMPK}$ 에 의존적인 경로와 비의존적인 경로 모두를 통하여 일어날 수 있다고 보고되었다 [13,14]. 따라서, 셀레늄에 의한 COX-2의 저해는 Akt의 활성억 제를 통해 일어나는 것뿐만 아니라 $\mathrm{AMPK}$ 와 같은 다른 신호 경로들의 조절을 통하여 일어날 수도 있다고 생각된다.

결론적으로, 본 연구를 통하여 셀레늄이 HT-29 세포의 증식
억제와 apoptosis를 유도하는 것이 밝혀졌으며, 이는 Akt와 COX-2 신호분자의 활성을 저해하는 것을 통해 일어나는 것으 로 보인다. 또한 셀레늄에 의한 세포증식억제효과에 있어서 $\mathrm{Akt}$ 의 조절이 매우 중요한 역할을 하는 것으로 나타났으며, Akt 신호분자의 저해가 셀레늄에 의한 세포증식억제 시너지 효과를 나타냄을 확인하였다. 그러나 본 연구결과를 통하여 Akt siRNA를 통한 Akt gene의 부재에도 COX-2의 발현이 나 타났으며, 이러한 조건에서 셀레늄이 COX-2의 발현을 억제하 는 것으로 보아 Akt가 존재하지 않을 때 COX-2의 조절에 있어 어떠한 신호분자들이 작용하는지 향후 진행될 연구과제로 여 겨진다.

\section{감사의 글}

본 연구는 지식경제부와 한국산업기술재단의 전략기술양 성사업 및 2011년 정부(교육과학기술부)의 재원으로 한국연구 재단의 지원을 받아 수행된 연구임(KRF-2010-0021402).

\section{References}

1. Bellacosa, A., C. C. Kumar, C. A. Di, and J. R. Testa. 2005. Activation of Akt kinases in cancer implications for therapeutic targeting. Adv. Cancer Res. 94, 29-86.

2. Carnero, A. 2010. The PKB/AKT pathway in cancer. Curr. Pharm Des. 16, 34-44

3. Chao, X., J. Zao, G. Xiao-Yi, M. Li-Jun, and S. Tao. 2010. Blocking of PI3K/AKT induces apoptosis by its effect on NF- $\mathrm{kB}$ activity in gastric carcinoma cell line SGC7901. Biomed Pharmacother. 64. 600-604.

4. Clark, L. C., G. F. Jr. Combs, B. W. Turnbull, E. H. Slate, D. K. Chalker, J. Chow, L. S. Davis, R. A. Glover, G. F. Graham, E. G. Gross, A. Krongrad, J. L. Jr. Lesher, H. K. Park, B. B. Jr. Sanders, C. L. Smith, and J. R. Taylor. 1996. Effects of selenium supplementation for cancer prevention in patients with carcinoma of the skin. A randomized controlled trial. Nutritional prevention of cancer trial. JAMA 276, 1957-1963.

5. El-Bayoumy, K. 2001. The protective role of selenium on genetic damage and on cancer. Mutat. Res. 475, 123-139.

6. Glynn, S. A., R. L. Prueitt, L. A. Ridnour, B. J. Boersma, T. M. Dorsey, D. A. Wink, J. E. Goodman, H. G. Yfantis, D. H. Lee, and S. Ambs. 2010. COX-2 activation is associated with Akt phosphorylation and poor survival in ER-negative, HER2-positive breast cancer. BMC Cancer 10, 626.

7. Gopalakrishna, R., Z. H. Chen, and U. Gundimeda. 1997. Seleno-compounds induce a redox modulation of protein kinase $\mathrm{C}$ in the cell, compartmentally independent from cytosolic glutathione: its role in inhibition of tumor promotion. Arch Biochem Biophys. 348, 37-48.

8. Han, Y. D., Y. K. Hong, J. G. Kang, Y. J. Choi, and C. H. Park. 2010. Relation of the expression of cyclooxygenase-2 in colorectal adenomas and adenocarcinomas to angio- 
genesis and prognosis. J. Korean Soc. Coloproctol. 26, 339-346.

9. Kada, F., M. Saji, and M. D. Ringel. 2004. Akt: a potential target for thyroid cancer therapy. Curr. Drug Targets Immune Endocr. Metabol. Disord 4, 181-185.

10. Korkaya, H., A. Paulson, E. Charafe-Jauffret, C. Ginestier, M. Brown, J. Dutcher, S. G. Clouthier, and M. S. Wicha. 2009. Regulation of mammary stem/progenitor cells by PTEN/Akt/beta-catenin signaling. PLoS Biol. 7, e1000121.

11. Lee, K. M., M. K. Hwang, D. E. Lee, K. W. Lee, and H. J. Lee. 2010. Protective effect of quercetin against arsenite-induced COX-2 expression by targeting PI3K in rat liver epithelial cells. J. Agric. Food Chem 58, 5815-5820.

12. Lee, S. H., S. Y. Park, I. S. Kim, O. J. Park, and Y. M. Kim 2010. The effect of combind treatment of selenium and curcumin on Akt and mTOR regulation in Hep3B hepato-carcinoma cells. Cancer Prev. Res. 15. 285-290.

13. Lee, Y. K., S. Y. Park, Y. M. Kim, and O. J. Park. 2009. Regulatory effect of the AMPK-COX-2 signaling pathway in curcumin-induced apoptosis in HT-29 colon cancer cells. Ann. N. Y. Acad Sci. 1171, 489-494.

14. Lee, Y. K., S. Y. Park, Y. M. Kim, D. C. Kim, W. S. Lee, Y. J. Surh, and O. J. Park. 2010. Suppression of mTOR via Akt-dependent and -independent mechanisms in selenium-treated colon cancer cells: involvement of AMPKalpha1. Carcinogenesis 31, 1092-1099.

15. Li, X. Y., X. R. Zhan, X. M. Liu, and X. C. Wang. 2011. CREB is a regulatory target for the protein kinase Akt/PKB in the differentiation of pancreatic ductal cells into islet $\beta$-cells mediated by hepatocyte growth factor. Biochem Biophys. Res. Commun. 404, 711-716.

16. Li, Y. B., J. Y. Han, W. Jiang, and J. Wang. 2011. Selenium inhibits high glucose-induced cyclooxygenase-2 and P-se- lectin expression in vascular endothelial cells. Mol. Biol. Rep. 38, 2301-2306.

17. Osaki, M., M. Oshimura, and H. Ito 2004. PI3K/Akt pathway: its functions and alterations in human cancer. Apoptosis 9, 667-676.

18. Rotruck, J. T., A. L. Pope, H. E. Ganther, A. B. Swanson, D. G. Hafeman, and W. G. 1973. Hoekstra. Selenium: biochemical role as a component of glutathione peroxidase. Science 179, 588-90.

19. Rotruck, J. T., W. G. Hoekstra, H. E. Ganther, and A. L. Pope. 1972. Prevention of oxidative damage to rat erythrocytes by dietary selenium. J. Nutr. 120, 689.

20. Rudolf, E., V. Králová, and M. Cervinka. 2008. Selenium and colon cancer--from chemoprevention to new treatment modality. Anticancer Agents Med Chem 8. 598-602.

21. Sinha, R., S. C. Kiley, J. X. Lu, H. J. Thompson, R. Moraes, S. Jaken, and D. Medina. 1999. Effects of methylselenocysteine on PKC activity, cdk2 phosphorylation and gadd gene expression in synchronized mouse mammary epithelial tumor cells. Cancer Lett. 146, 135-145.

22. Tang, C. H., R. S. Yang, T. H. Huang, D. Y. Lu, W. J. Chuang, T. F. Huang, and W. M. Fu. 2006. Ultrasound stimulates cyclooxygenase-2 expression and increases bone formation through integrin, focal adhesion kinase, phosphatidylinositol 3-kinase, and Akt pathway in osteoblasts. Mol. Pharmacol. 69, 2047-2057.

23. Yamauchi, T., M. Watanabe, T. Kubota, H. Hasegawa, Y. Ishii, T. Endo, Y. Kabeshima, K. Yorozuya, K. Yamamoto M. Mukai, and M. Kitajima. 2002. Cyclooxygenase-2 expression as a new marker for patients with colorectal cancer. Dis. Colon Rectum 45, 98-103.

\section{초록 : HT-29 대장암세포에서 Akt 활성 저해에 따른 셀레늄의 세포 증식억제 효과}

박송이 ${ }^{1} \cdot$ 김인섭 $^{1} \cdot$ 이세희 ${ }^{1} \cdot$ 이솔화 ${ }^{1} \cdot$ 정다운 ${ }^{1} \cdot$ 박옥진 $^{2} \cdot$ 김영민 $^{1}{ }^{*}$

(한남대학교 생명나노과학대학 생명과학과, ${ }^{2}$ 한남대학교 생명나노과학대학 식품영양학과)

$\mathrm{Akt}$ 는 세포의 증식과 분화에 관여하며 많은 암종에서 과발현되어 있다는 것이 보고되었다. 본 연구에서는 Akt 의 조절을 통한 셀레늄의 HT-29 세포의 세포증식억제 시너지효과를 확인하였다. 셀레늄을 농도별과 시간별로 처리하였을 때 HT-29 세포의 증식이 억제되었고, apoptosis가 일어남을 확인하였다. 셀레늄을 농도별로 처리하여 Western blotting 및 immunofluorescence를 실시한 결과 Akt의 인산화가 저해되었고 COX-2의 발현도 저해되었 다. 또한 Akt 저해제인 LY294002를 처리한 결과, HT-29 대장암세포의 증식이 억제되었으며, LY294002를 셀레늄 과 병행처리하였을 때 셀레늄에 의한 세포증식억제 효과가 더 강하게 나타나는 것을 확인하였다. Akt siRNA에 의한 Akt의 불활성화는 non-transfected 세포에 비하여 HT-29 세포의 성장을 더 강하게 억제하였으며, Akt가 불 활성화 되었을 때 COX-2의 발현 역시 non-transfected 세포에 비하여 감소된 것을 확인하였다. 따라서 HT-29 세 포에서 셀레늄의 세포증식억제 효과는 Akt와 COX-2 신호분자의 조절을 통해 일어나며, Akt 의 저해는 셀레늄의 대장암세포증식 억제에 시너지 효과를 나타냄을 확인하였다. 